\title{
VALIDITY OF DOCUMENTARY VIDEO LEARNING MEDIA BASED ON LOCAL CONTENT OF TRADITIONAL MUSICAL INSTRUMENTS ON THE MATERIAL OF SOUND WAVES
}

\author{
Hisbulloh Als Mustofa*, Gunawan, and Kosim \\ Physic Education Department, FTTE University of Mataram, Mataram, Indonesia. \\ Email: hisbulloham@gmail.com
}

Acceped: Sept 01 2021. Approved: Nov 01 2021. Published: Nov 112021

\begin{abstract}
This study aims to determine the validity of the documentary video learning media based on local content of traditional musical instruments on material of sound waves. This type of research is a research and development which adopts a 4D (Define, Design, Develop, and Disseminate) model developed by Thiagarajan. The validity of the product development in this study was tested for validity by 3 physics education expert lecturers and 3 physics teacher practitioners. The results of this study indicated that the documentary video learning media is feasible to proceed to the operational trial phase of learning. Based on the assessment by the valuators, it obtained an average value of $93 \%$ with a very good category, while from the results of student responses by limited trial to this documentary video learning media, it obtained an average value of $89 \%$ with a very good category.
\end{abstract}

Keywords: Learning Media, Video Documentary, local content, traditional music, sound waves.

\section{INTRODUCTION}

Corona Virus Disease (COVID-19) which is caused by SARS-CoV-2 has been a global pandemic. The pandemic is impacting various sectors of life, including the education sector. Learning from Home implements Distance Learning system. All learning activities must be carried out by online communication. Based on research conducted by Purwanto [1] that students and teachers consider the online learning system to be less effective, some of the constraint factors include unsuitable learning models, unattractive learning media, difficulty to focus, many tasks, limited internet quota, and students' lack motivation in participating in learning activities. Meanwhile, most of the teachers can't keep up with changes, can't adapt to the online learning system, and can't apply and make a use of supporting devices properly [2]. Based on the things mentioned above, it can be concluded that both institution and students are not ready to this current situation, so does the Physics learning. Therefore, teachers are required keep up with the changes and continue to be innovative and creative.

Innovation to Physics learning is urgently needed to support the learning process. The Physics itself consists of abstract and conceptual materials which require students to visualize them [3]. According to research conducted by Kharisma et al [4] Physics is one of the subjects that experience problems during online learning. The online learning in which gives no direct explanation leads to students' understanding and motivation to decrease. Material of Sound Waves places first as the material students find difficult to understand, because the material contains many events which are hard to be visualized [5]. In visualizing concepts and phenomenon on sound wave material, a learning media is needed because the existence of learning media can emerge interests, motivation, desire, and stimulation in learning activities [6].

The chosen learning media must be suitable for the conditions and delivered materials. Media used in the online learning must be flexible with no limits of space and time. In addition, the learning media must be useful not only to visualize the material but also to produce audio illustrations, making it a suitable media to the Sound Wave material. This is in line with research conducted by Hasmar et al [5] that video media is the right choice to help students' learning process, it can explain the material which is needed to yet hard to visualize, such as material of sound waves. There are various types of learning videos, one of which is a documentary video. The documentary video learning media was chosen because it has advantages in delivering the material content which contains physical events or phenomenon without having to practice it directly, this is in accordance with the concept of learning from home. In addition, students can directly view the physical phenomenon in simple experiments [7].

The documentary video can contain events and phenomena of everyday life that are close to students so that learning can be more meaningful and contextual if it is designed according to the way humans live [8]. In order to make a meaningful and contextual learning, it will be a good way of learning if the Physics material is integrated with the local wisdom around where the students live. Integrating physics material with local wisdom is not only aimed to make it easier for students to understand physics material but also to make students being familiar with their own 
local wisdom which surrounds them which nowadays is gradually replaced by foreign cultures [9]. Each regional has its own potential and characteristic of local wisdom. One of the local potential of NTB is traditional instruments, such as Gamelan. Musical instrument base of Gamelan reflects many Physical concepts [10]. The use of this traditional musical instrument can be integrated with sound wave material to explain the concept of vibration as a sound source, the scales of strings and organ pipes, the Doppler Effect, the intensity and level of sound intensity. Local content of the traditional musical instrument is suitable to be integrated in the learning media of documentary video.

Based on the description above, researchers have developed a learning media of documentary video by integrating Physics material and traditional musical instrument to explain the material of Sound Wave. A sudden transition of the learning system impacts the system itself, not optimal adaption, less innovative and creative learning media to carry the learning process during the current situation emerges the researcher to develop a media which is a potential answers during this time. This far, the learning media of documentary video based on traditional music content on the material of sound waves has never been developed as one of the supporting media of Physics learnin. Based on these considerations, the researchers have developed a learning media which implements traditional musical instrument on sound wave material in the form of documentary video.

\section{RESEARCH METHODS}

The type of the study is a Research and Development study which adopts the model of 4D (Define, Design, Develop, and Disseminate) developed by Thiagarajan [11]. The developed product was a learning media in the form of documentary video based on local content which is traditional instrument media in the learning material of Sound Waves.

1. Development Stage of Learning Media

a. Define

Define is an early stage which aims to get information about the students' characteristic, the problems during the learning process, method of learning, learning media, and curriculum review.

b. Design

Design step obtained a draft of documentary video learning media.

c. Develop

The purpose of the develop step is to produce a validated learning media in the form of documentary video, been revised by the suggestions of valuators, and been passing a limited trial to students of Physics Education Department of Faculty of Education and Teacher Training, Mataram University.

d. Disseminate

Disseminate step aims to disseminate the developed product to website and YouTube, the product can be accessed via the page bellow.

https://www.youtube.com/watch?v=5JWaf5eBy_I\& $\mathrm{t}=3 \mathrm{~s}$.

2. Data Collection Instrument

The data collection method to determine the feasibility of the learning media based on the local content of traditional musical instrument in the form of documentary video on the material of Sound Waves is validity test. Validity sheet was used to determine the value of the developed learning media by valuators, also to get suggestions for the purpose of revision. The data was collected by sheets of expert judgment and students' responses and was analyzed using Likert scale.

$$
P=\frac{f}{N} \times 100 \%
$$

Description:

$\mathrm{f}=$ gained score

$\mathrm{N}=$ maximum score

$\mathrm{P}=$ percentage

Questionnaire response applied 4 choices of answer according to the content of the question. The change of the results in the form of letter to score based on the provision of the Rating Scale shown in the Table 1 bellow:

Tabel 1. Assessment Score to the answer choices

\begin{tabular}{lc}
\hline Answer Choices & Score \\
\hline Good & 4 \\
Satisfactory & 3 \\
Less than satisfactory & 2 \\
Not good & 1 \\
\hline
\end{tabular}

Validation questionnaire and response apply 4 choices according to the content of questions. The percentage data then was converted to the feasibility criteria of learning media, presented in the following Table 2 .

Tabel 2. Feasibility criteria of Learning Media

\begin{tabular}{ll}
\hline Persentase & Feasibility criteria \\
\hline $80,1 \%-100 \%$ & Very feasible \\
$70,1 \%-80 \%$ & Feasible enough \\
$50,1 \%-70 \%$ & Less feasible \\
$1 \%-50 \%$ & Not feasible \\
\hline
\end{tabular}




\section{RESULTS AND DISCUSSION}

The results of the study consist of the results of the 4D model research stages, namely define, design, develop, and disseminate stages. The initial analysis found various problems, one of which was the change of the learning system from normal to online, it has a great impact to the learning system itself, particularly the subject of Physics. Physics learning consists of many learning materials, one of which that is considered difficult and impacted a lot is Sound Waves material. The lack of teachers' capability is responsible to the less effective learning process [12]. The concept identification of the Sound Wave learning material was carried next in order to design the initial draft of documentary learning video.

The result of the develop stage was documentary learning video based on the local content of traditional musical instrument. The feasibility of the media then tested and revised based on the assessments and suggestions of the valuators and the respondents. The details of suggestions and revisions are presented in the following Table 3 and Table 4.

Tabel 3. Revisions of Documentary Video Learning Media Based on the Local Content of Traditional Music Instrument from the Valuators Assessments

\begin{tabular}{lll}
\hline No. & \multicolumn{1}{c}{ Suggestion } & \multicolumn{1}{c}{ Revision } \\
\hline 1 & $\begin{array}{l}\text { The translation of the material subtitle } \\
\text { should be more contrast and clear }\end{array}$ & $\begin{array}{l}\text { Improve the color selection } \\
\text { of the translation subtitle of } \\
\text { the text }\end{array}$ \\
& $\begin{array}{l}\text { The height of sound frequency doesn't } \\
\text { always show the volume of the sound. }\end{array}$ & Add the information and \\
High volume related to the intensity of \\
the sound
\end{tabular}

Tabel 4. Revisions of Documentary Video Learning Media Based on the Local Content of Traditional Music Instrument from the Respondents' Responses.

\begin{tabular}{|c|c|c|}
\hline No & Suggestion & Revision \\
\hline 1 & Very good and easy to understand & - \\
\hline 2 & $\begin{array}{l}\text { Adding more problems examples to the learning } \\
\text { media }\end{array}$ & Add problem examples \\
\hline 3 & The font should be made larger & Adding the size of the fonts \\
\hline 4 & $\begin{array}{l}\text { Documentary video learning media motivates students } \\
\text { a lot to, eases them to understand, learns the term of } \\
\text { making video }\end{array}$ & - \\
\hline 5 & The documentary video learning media is very good & - \\
\hline 6 & $\begin{array}{l}\text { The wind back sound can clearly be heard, therefore } \\
\text { the sound should be given noise reduction while the } \\
\text { rest is good }\end{array}$ & $\begin{array}{l}\text { Fixing the sound problems and adding noise } \\
\text { reduction to the video }\end{array}$ \\
\hline 7 & $\begin{array}{l}\text { The learning video is very good and gives insight } \\
\text { about the traditional musical instruments in which we } \\
\text { rarely hear about these days }\end{array}$ & - \\
\hline 8 & $\begin{array}{l}\text { The media is creative and it can be a supporting media } \\
\text { of the Physics learning process }\end{array}$ & - \\
\hline 9 & - & - \\
\hline 10 & $\begin{array}{l}\text { The developed learning media integrates the material } \\
\text { of sound wave and local content, it gives motivation. }\end{array}$ & - \\
\hline 11 & The sound noise can still be heard & Adding noise reduction \\
\hline 12 & The video is good and attractive & - \\
\hline 13 & An attractive media to be developed & - \\
\hline 14 & $\begin{array}{l}\text { The learning video is attractive with a series of good } \\
\text { and clear animation, but the exploration of other } \\
\text { traditional musical instruments should be done next. }\end{array}$ & Giving more examples of instruments \\
\hline 15 & The sound noise can still be heard & Adding noise reduction \\
\hline
\end{tabular}


The feasibility of the learning media was measured based on the Likert scale. The assessments results of the developed learning media from valuators and practitioners are presented respectively on the Table 5 and Table 6 . Based on the feasibility results of the learning media from valuators, the average value was $93 \%$ in the category of very feasible.

Based on the results shown above, the average value from the practitioners was $89 \%$ in the category of very feasible.

The assessments of the developed learning media is in the category of very feasible because the value is above $80.1 \%$.

Documentary video of the learning media based on the local content was finished and valued very feasible. The development of the learning media adopts the 4D model consists of define, design, develop, and disseminate. The initial step of the media making was done by designing the learning media and material analyzing of Sound Waves material. The design of the media used several supporting software, namely Adobe Premiere Pro Cc 2020, Adobe Photoshop CC 2020, dand Adobe After Effect CC 2020. The results of the step was the draft of documentary video which was valued by the valuators and practitioners. The data of the study was collected by validity sheet to valuators and questionnaire to practitioners namely students of Physics Education, and the Likert scale was used in the data collection score.

The validity sheet consists of several aspects namely, appearance, sound and audio, language, implementation and convenience, documentary video characteristics, validity, material, and local content characteristics. The aspects were being the standard to conduct the feasibility test.

Firstly, the appearance aspect of the learning media, the results showed that the learning media has good quality of images, animations, and texts. The video with a good quality can be a supporting media of students to learn and ease them to understand. This is in accordance with the previous study that explains that visuals can increase student interest and give a good bridge in between the learning material and its implementation In addition, based on the valuators suggestions and respondents' responses, the size of the text had been revised, the media is expected to have a good readability [13]. This is in accordance to the previous study which stated that the size of the text affects the information, therefore the size of the text must be clear.
Tabel 5. The results of feasibility analysis of the documentary video learning media based on the local content of traditional musical instruments from valuators

\begin{tabular}{|c|c|c|c|}
\hline No. & Aspects & Percentage & Category \\
\hline 1 & Appearance & $99 \%$ & $\begin{array}{l}\text { Very } \\
\text { feasible }\end{array}$ \\
\hline 2 & Sound and audio & $98 \%$ & $\begin{array}{l}\text { Very } \\
\text { feasible }\end{array}$ \\
\hline 3 & Language & $95 \%$ & $\begin{array}{l}\text { Very } \\
\text { feasible }\end{array}$ \\
\hline 4 & $\begin{array}{l}\text { Implementation } \\
\text { and } \\
\text { Convenience }\end{array}$ & $90 \%$ & $\begin{array}{l}\text { Very } \\
\text { feasible }\end{array}$ \\
\hline 5 & $\begin{array}{l}\text { Documentary } \\
\text { video } \\
\text { characteristics }\end{array}$ & $90 \%$ & $\begin{array}{l}\text { Very } \\
\text { feasible }\end{array}$ \\
\hline 6 & Material & $90 \%$ & $\begin{array}{l}\text { Very } \\
\text { feasible }\end{array}$ \\
\hline 7 & Validity & $88 \%$ & $\begin{array}{l}\text { Very } \\
\text { feasible }\end{array}$ \\
\hline 8 & $\begin{array}{l}\text { Local content } \\
\text { characteristics }\end{array}$ & $98 \%$ & $\begin{array}{l}\text { Very } \\
\text { feasible }\end{array}$ \\
\hline $\begin{array}{l}\text { Ave } \\
\text { pero }\end{array}$ & $\begin{array}{l}\text { ge } \\
\text { tage }\end{array}$ & $93 \%$ & $\begin{array}{l}\text { Very } \\
\text { feasible }\end{array}$ \\
\hline
\end{tabular}

Tabel 6 . The results of feasibility analysis of the documentary video learning media based on the local content of traditional musical instruments based on the limited trial

\begin{tabular}{|c|c|c|c|}
\hline No & Aspects & Percentage & Category \\
\hline 1 & Appearance & $90 \%$ & $\begin{array}{l}\text { Very } \\
\text { feasible }\end{array}$ \\
\hline 2 & Sound and audio & $85 \%$ & $\begin{array}{l}\text { Very } \\
\text { feasible }\end{array}$ \\
\hline 3 & Language & $84 \%$ & $\begin{array}{l}\text { Very } \\
\text { feasible }\end{array}$ \\
\hline 4 & $\begin{array}{l}\text { Implementation } \\
\text { and Convenience }\end{array}$ & $91 \%$ & $\begin{array}{l}\text { Very } \\
\text { feasible }\end{array}$ \\
\hline 5 & $\begin{array}{l}\text { Documentary } \\
\text { video } \\
\text { characteristics }\end{array}$ & $93 \%$ & $\begin{array}{l}\text { Very } \\
\text { feasible }\end{array}$ \\
\hline 6 & Material & $87 \%$ & $\begin{array}{l}\text { Very } \\
\text { feasible }\end{array}$ \\
\hline 7 & Validity & $90 \%$ & $\begin{array}{l}\text { Very } \\
\text { feasible }\end{array}$ \\
\hline 8 & $\begin{array}{l}\text { Local content } \\
\text { characteristics }\end{array}$ & $90 \%$ & $\begin{array}{l}\text { Very } \\
\text { feasible }\end{array}$ \\
\hline $\begin{array}{l}\text { Ave } \\
\text { pero }\end{array}$ & $\begin{array}{l}\text { ge } \\
\text { ntage }\end{array}$ & $89 \%$ & $\begin{array}{l}\text { Very } \\
\text { feasible }\end{array}$ \\
\hline
\end{tabular}




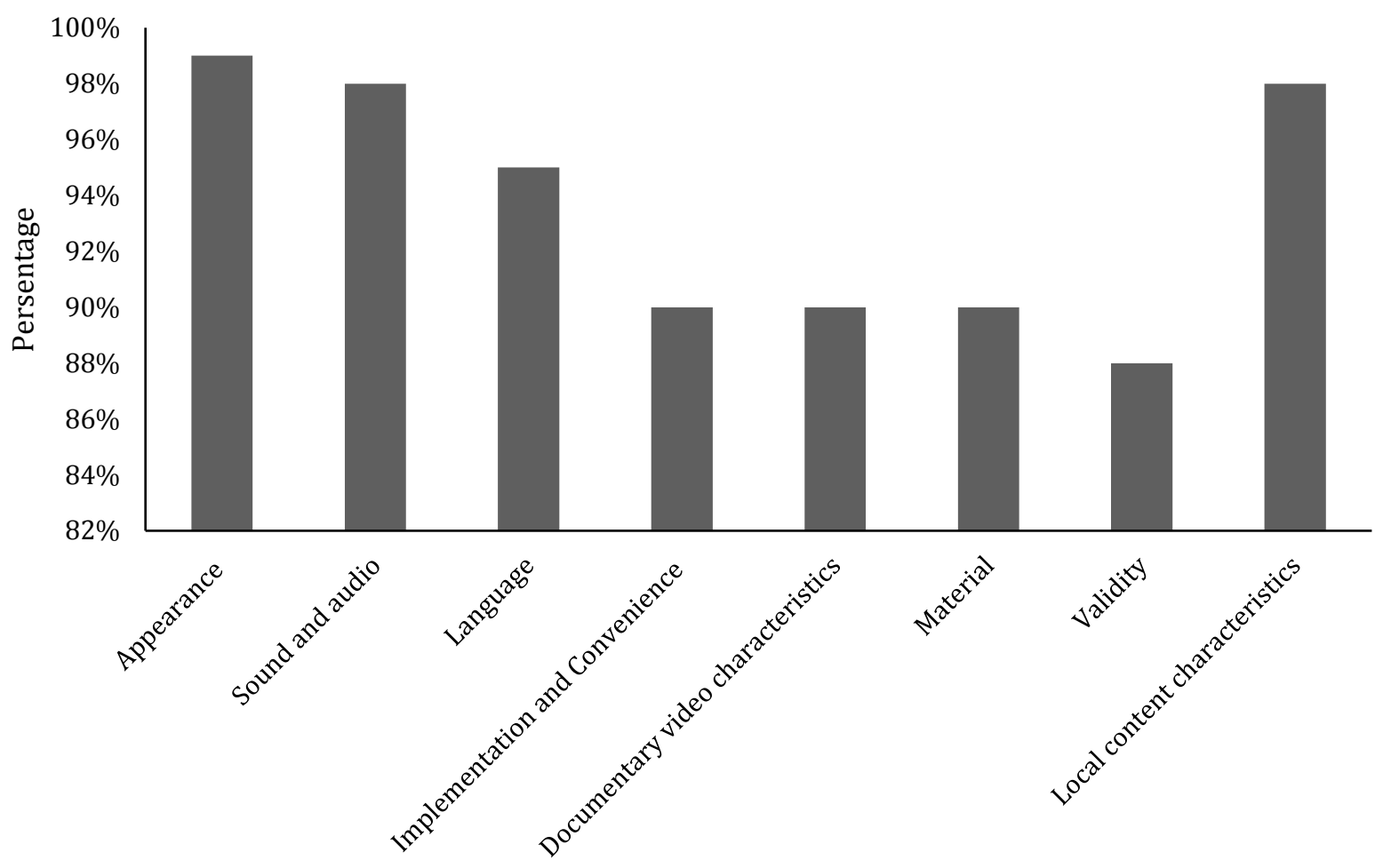

Aspects

Figure 1. Feasibility analysis of the documentary video learning media based on the local content of traditional musical instruments

Secondly, the sound and audio aspect, according to the back sound, dubbing, and mixing of the back sound, vocal, and sample was valued very feasible. The supporting aspect is expected to deliver the learning material in a good way so that it can help student to understand the material better. The audio of narrator explanation aims to ease students understand the material and minimize the possibility of misunderstandings. The back sound also creates a supportive situation in the documentary video [15].

Thirdly, the language aspect was valued very feasible according to the selection of words which doesn't give double interpretation and easy to understand. The selected words of the video documentary should be consistent, communicative and efficient to help students understand [13]. Therefore, the language aspect is considered important.

The important aspect that should be considered in the making and the result of the documentary video is the implementation and convenience of the video itself. The aspect in the video was valued very feasible due to its flexibility in the implementation. The aspect of documentary video characteristics was also valued very feasible according to the content which provides information of the material implementation, it can make students feel interested and motivated, and this is in accordance to the previous study that explained that the learning process should consider the needs of students, their characteristics and way of learning [14].

Learning media should provide learning material for students to learn. The material content aspect was valued very feasible according to the material it provides which is clear, relevant, well illustrated, and in accordance to the syllabus, basic competencies, systematic design of the learning material, learning purposes, concepts, and students' intellectual development level, which all are well designed to help students to understand. This is in accordance with the study conducted previously that the learning media should be based on the scope of the learning material itself [16].

The validity of the learning media was in the category of very feasible according to the presentation of the media which is not leading to double interpretation, the presented events in accordance to the principles, theories, and laws of the basic knowledge. This is in accordance to the previous study that the learning media should minimize the possibility of misunderstanding in a depth way [17].

Lastly, the aspect of local content characteristics was also valued very feasible according to the way the implementation of the learning media presented in the term of local 
wisdom. It also gives insight of the local potential of traditional musical instruments. The result is in line with the previous study which explained that traditional musical instrument of Gamelan can be used to explain the Sound Wave learning material.

Based on the results, the average score of feasibility test obtained from valuators was $93 \%$ and $89 \%$ from the limited trial. The obtained average score was $P \geq 81 \%$ leading the documentary video in the category of very feasible [18]. The result of the study is in accordance with the study conducted previously [7], [19] and [20] about the documentary video that is proved to be very feasible to apply as the learning media.

\section{CONCLUSION}

Based on the discussions above, the documentary video learning media based on the local content of traditional musical instruments is very feasible according to the results percentage from the valuators and students' responses respectively $93 \%$ and $89 \%$, according to the results, it can be concluded that the developed documentary video can be implemented as one of the learning media of Physics subject.

\section{REFERENCES}

[1] Purwanto, A. dll (2020). Studi EksploratifDampak Pandemi COVID-19 Terhadap Proses Pembelajaran Online di Sekolah Dasar. EduPsyCouns: Journal of Education, Psychology and Counseling. 2(1), $1-12$.

[2] Asmuni. (2020). Problematika Pembelajaran Daring di Masa Pandemi Covid-19 dan Solusi Pemecahannya. Jurnal Paedagogy: Jurnal Penelitian dan Pengembangan Pendidikan. 7(4). 281-288.

[3] Gunawan, G., Harjono, A., \& Imran, I. (2015). Pengaruh Multimedia Interaktif dan Gaya Belajar Terhadap Penguasaan Konsep Kalor Siswa. Jurnal Pendidikan Fisika Indonesia, 12(2), 118-125.

[4] Kharisma, N. N., Roesminingsih, M. V dan Suhanadji. (2020). Gambaran Kebutuhan Pembelajaran Daring PKBM Budi Utama Surabaya Pada Masa Pandemi Covid-19. Jurnal Pendidikan Nonformal. 15(1). 38-44

[5] Hasmar. A.F., Siswoyo, \& Rustana. C.E. (2020). Pengembangan Video Pembelajaran Gelombang Bunyi Menggunakan Model Problem Based Learning ( $\mathrm{Pbl})$. Prosiding Seminar Nasional Fisika (E-Journal) SNF(2020), Jakarta, Indonesia: Universitas Negeri Jakarta. https://doi.org/10.21009/03.SNF(2020)

[6] Yunita, E. \& Suprapto, N. (2021). Analisis Kelayakan Video Pembelajaran Fisika Berbasis Platform Youtube Pada Materi
Usaha Dan Energi. IPF:Inovasi Pendidikan Fisika. 10 (1), 21-31.

[7] Suryandari, Sunarno, W., dan Suparmi. (2016). Pengembangan Media Pembelajaran Menggunakan Video Dokumenter Berbasis Inkuiri Terbimbing Berorientasi Pada Motivasi Belajar Siswa. Jurnal Inkuiri. 5(1), 85-94.

[8] Gunawan, G., Harjono, A., \& Sutrio, S. (2016). Multimedia Interaktif dalam Pembelajaran Konsep Listrik bagi Calon Guru. Jurnal Pendidikan Fisika dan Teknologi, 1(1), 9-14

[9] Oktaviana, D., Hartini, S., \& Misbah. (2017). Pengembangan Modul Fisika Berintegrasi Kearifan Lokal Membuat Minyak Lala Untuk Melatih Karakter Sanggam. Berkala Ilmiah Pendidikan Fisika 5(3). 272-285.

[10] Nursulistyo, E. (2019). Pemanfaatan Siter, Kendang, Saron, Kenong, dan Gender sebagai media pembelajaran fisika. JRKPF UAD 6(1). 5-9.

[11] Sugiono. (2013). Metode Penelitian Kuantitatif Kualitatif Dan $R$ \&. D. Bandung : Alfabeta

[12] Mutaqinah, R, \& Hidayatullah, T. (2020). Implementasi Pembelajaran Daring (Program BDR) Selama Pandemi Covid-19 di Provinsi Jawa Barat. Jurnal PETIK. 6(2), 86-92

[13] Panjaitan, R.G.D., Wahyuni, E.S., \& Mega. (2019). Film Dokumenter Sebagai Media Pembelajaran Submateri Zat Aditif. JPBIO (Jurnal Pendidikan Biologi). 4(2), 52 - 59.

[14] Rahmawati, I. S., Roekhan, dan Nurchasanah. (2016). Pengembangan Media Pembelajaran Menulis Teks Fabel Dengan Macromedia Flash Bagi Siswa SMP. Jurnal Pendidikan: Teori, Penelitian, dan Pengembangan. Vol. 1, No. 7: 1323-1329.

[15] Sadiman, A.S., Rahardjo, R., Haryono A., \& Rahardjito. (2012). Media pendidikan: pengertian, pengembangan, dan pemanfaatannya. Jakarta: Rajawali.

[16] Ekawati, I., Panjaitan, R.G.P., \& Wahyuni, E.S. (2017). Pengembangan Film Dokumenter Sebagai Media Pembelajaran Submateri Gangguan Sistem Ekskresi Kelas XI Sma. Jurnal Pendidikan dan Pembelajaran Khatulistiwa. 6(7), 1-9.

[17] Zukhruf, K. D., Khaldun, I., \& Ilyas, S. (2016). Remediasi Miskonsepsi Dengan Menggunakan Media Pembelajaran Interaktif Pada Materi Fluida Stati. Jurnal Pendidikan Sains Indonesia, 4(2), 56-68.

[18] Arikunto, Suharsimi. (2006). Prosedur Penelitian Suatu Pendekatan Praktik. Jakarta: PT Rhineka Cipta.

[19] Widianta, I.M.N. (2021). Video Pembelajaran Fisika Sebagai Sumber Belajar Daring untuk 
J. Pijar MIPA, Vol. 16 No.5, November 2021: 576-582

Meningkatkan Motivasi Belajar Peserta Didik SMAN 9 Mataram di Masa Pandemi Covid19. Jurnal Pedagogy : Jurnal Penelitian dan Pengembangan Pendidikan. 8(3), 377-385.

[20] Nurhuda, A., Syamswisna, \&Marlina, R. (2021). Kelayakan Film Dokumenter Sebagai Media Pembelajaran Konsep Keanekaragaman Gen, Jenis, Ekosistem Di Kelas X. Jurnal Pendidikan Dan Pembelajaran Khatulistiwa. 8(11), 1-13. 